\title{
GENE MAPPING IN AN ANOPHTHALMIC PEDIGREE OF A CONSANGUINEOUS PAKISTANI FAMILY OPENED NEW HORIZONS FOR RESEARCH
}

\author{
Saleha $\mathrm{S}^{1^{*}}$, Ajmal $\mathrm{M}^{2}$, Zafar $\mathrm{S}^{3}$, Hameed $\mathrm{A}^{2}$
}

\begin{abstract}
*Corresponding Author: Dr. Shamim Saleha, Department of Biotechnology and Genetic Engineering, Kohat University of Science and Technology, Kohat 26000, Khyber Paktunkhwa, Pakistan. Tel: +92-922-5291-4659. Cell: +92-333-964-2532. Fax:+92-922-554-556. E-mail: shamimsaleha@yahoo.com
\end{abstract}

\begin{abstract}
Clinical anophthalmia is a rare inherited disease of the eye and phenotype refers to the absence of ocular tissue in the orbit of eye. Patients may have unilateral or bilateral anophthalmia, and generally have short palpebral fissures and small orbits. Anophthalmia may be isolated or associated with a broader syndrome and may have genetic or environmental causes. However, genetic cause has been defined in only a small proportion of cases, therefore, a consanguineous Pakistani family of the Pashtoon ethnic group, with isolated clinical anophthalmia was investigated using linkage mapping. A family pedigree was created to trace the possible mode of inheritance of the disease. Blood samples were collected from affected as well as normal members of this family, and screened for disease-associated mutations. This family was analyzed for linkage to all the known loci of clinical anophthalmia, using microsatellite short tandem repeat (STR) markers. Direct sequencing was performed to find out disease-associated mutations in the candidate gene. This family with isolated clinical anophthalmia, was mapped to the $S O X 2$ gene that is located at chromosome 3q26.3-q27. However, on exonic and regulatory regions mutation screening of the $S O X 2$ gene, the disease-associated mutation was not identi-

\footnotetext{
${ }^{1}$ Department of Biotechnology and Genetic Engineering, Kohat University of Science and Technology, Kohat, Khyber Paktunkhwa, Pakistan Islamabad, Pakistan

${ }^{3}$ Pakistan Institute of Medical Sciences (PIMS) Islamabad, Pakistan
}

${ }^{2}$ Institute of Biomedical and Genetic Engineering (IBGE),
\end{abstract}

fied. It showed that another gene responsible for development of the eye might be present at chromosome 3q26.3-q27 and needs to be identified and screened for the disease-associated mutation in this family.

Keywords: Isolated clinical anophthalmia; Khyber Pukhtunkwa; Linkage analysis; Mutation screening; Pashtoon ethnic family; SOX2 gene.

\section{INTRODUCTION}

Clinical anophthalmia is a rare genetic disease of the eye and phenotype refers to the absence of ocular tissue in the orbit of eye [1-3]. Congenital clinical anophthalmia is commonly bilateral [4] but it may also be unilateral [5]. Often anophthalmia is part of a syndrome and is accompanied by other brain anomalies $[6,7]$. Clinically, in the absence of apparent ocular tissue, congenital anophthalmia and extreme microphthalmia (A/M), i.e., the presence of a small eye, are considered the same, because computerized tomography (CT) scan investigations indicated residual neuroectoderm in the orbit of the eye in some cases [8].

Clinical anophthalmia exhibits different patterns of genetic inheritance, i.e. autosomal dominant, autosomal recessive and X-linked recessive $[4,9]$. Studies on autosomal recessive mode of inheritance of anophthalmia have rarely been reported $[1,10]$. Similarly, previous research studies have also provided rare evidence about consanguinity association with congenital anophthalmia $[8,11]$.

Anophthalmia/microphthalmia cause a considerable percentage of congenital visual impairments 
in children [12]. Epidemiological data has reported that the prevalence of congenital anophthalmia is three in 100,000 . However, other evidence estimated the combined prevalence of congenital anophthalmia and microphthalmia up to three in $100,000[13,14]$. In developed countries, a prevalence of 0.2-0.4 per 10,000 births has been reported [15-17]. Epidemiological studies have also investigated some risk factors for anophthalmia including late maternal age, multiple births $[15,16]$, low birth weight and premature birth complications [18]. Epidemiological studies have reported that both genetic and environmental factors cause anophthalmia and microphthalmia, however, environmental factors account for a lesser number of cases [4].

Genetic linkage analysis studies have identified the same loci and mutations in the same genes for both clinical anophthalmia and extreme microphthalmia [4]. It was considered that congenital $\mathrm{A} / \mathrm{M}$ showed genetic heterogeneity due to linkage of a large number of loci with them. Similarly, mutations in several well-defined human genes such as CHX10, RAX, SOX2 and OTX2, are also associated with heritable forms of clinical anophthalmia and severe microphthalmia [9].

In the Khyber Pakhtunkhwa region of Pakistan, different Pashtoon tribes are prominent ethnic groups and due to cultural impacts, they have very strong reservations regarding marriages outside their tribal boundaries, as they believe that dilution of tribal blood may result in losing their specific tribal characteristics. Moreover, they practice consanguineous marriages to strengthen family ties and to maintain the family structure and property [19]. The causes of congenital inherited diseases in Khyber Pakhtunkhwa are maternal illiteracy, mother's age to be less than 20 years at the birth of first child, birth interval of less than 18 months [20], and the influencing culture factor to have more children, particularly sons, until menopause. The lack of public awareness toward prenatal diagnosis or prevention of inherited disease and health risks associated with consanguineous unions, is limited. Many people do not agree with medical explanations of a genetic mode of disease inheritance, even in case where there is an affected child. Because of this, inherited diseases are frequently observed in Khyber Pakhtunkhwa that follow Mendelian patterns of inheritance, and the molecular bases are not known. In present study, a consanguineous Pakistani family of the Pashtoon ethnic group with isolated clinical anophthalmia in Khyber Pakhtunkhwa was investigated.

\section{MATERIALS AND METHODS}

Ascertainment of Family. This study was approved by the Ethics Committee of the Department of Biotechnology and Genetic Engineering, Kohat University of Science and Technology, Khyber Pakhtunkhwa, Pakistan. A consanguineous Pakistani family of the Pashtoon ethnic group with bilateral clinical anophthalmia, in which disease was segregating as an autosomal recessive trait, was ascertained. This family resided in the southern region of Khyber Paktunkhwa, Pakistan, known as Kohat, which is inhabited by various Pashtoon tribes (Figure 1). It was observed that ocular tissue was absent in the orbit of the eyes in affected offspring (Figure 2). On the basis of clinical features assessed by slit lamp examination and radiological assessment by CT scanning, the ophthalmologist diagnosed the

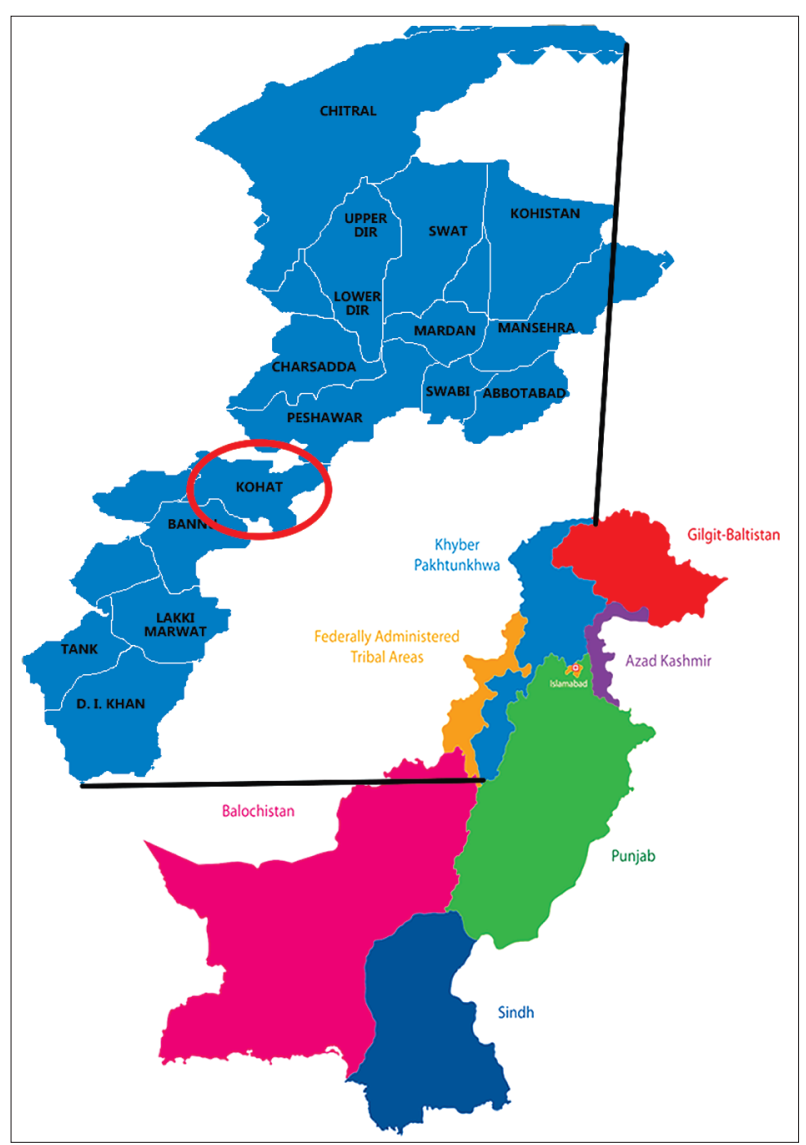

Figure 1. Map of Pakistan showing the provincial subdivisons; detailed map of Khyber Pakhtunkhwa with the Kohat region highlighted. 


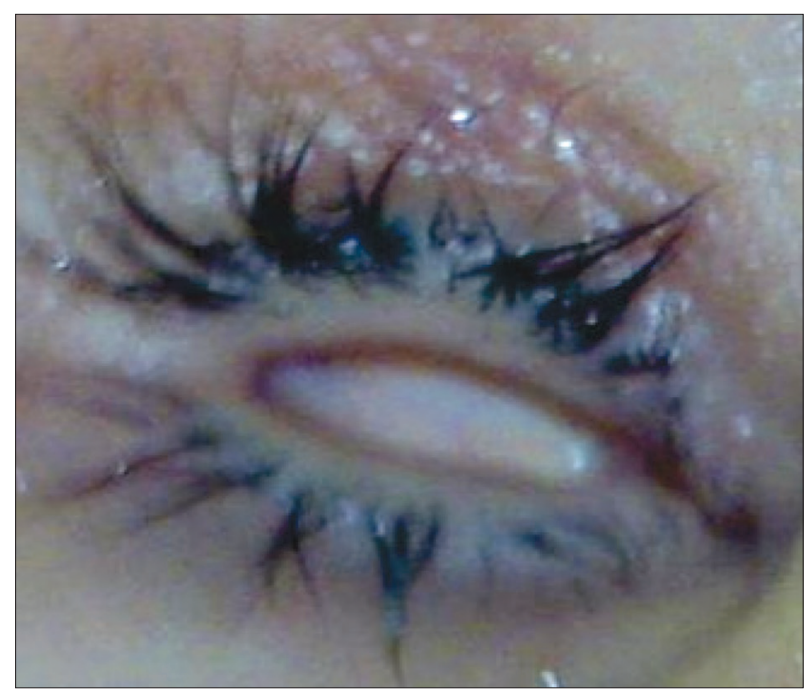

Figure 2. Photograph of the eye of an anophthalmic patient of a Pakistani family.

anophthalmia as an isolated entity and having no syndromic presentation in the affected daughters. Written informed consent was obtained from the elders of this family to participate in the study. A pedigree of the family was created from information provided by the family using the Cyrillic (version 2.10) program (http://www. cherwell.com).

Blood Sample Collection and DNA Extraction. Blood samples were collected in $10 \mathrm{~mL}$ vacutainer tubes (Becton Dickinson, Mountain View, CA, USA) with written informed consent from six indi- viduals including four clinically normal (2MOP001, 2MOP002, 2MOP004, and 2MOP005), and two affected (2MOP003, and 2MOP006) daughters of this family. Genomic DNA was extracted from peripheral blood samples following the standard phenolchloroform extraction procedure [21].

Genotyping and Linkage Analysis. Identification of the locus responsible for the isolated clinical anophthalmia phenotype in the selected family, genomic DNA from each individual was genotyped using a microsatellite short tandem repeat (STR) marker for the known clinical anophthalmia loci (Table 1). The microsatellite markers for each locus were amplified by polymerase chain reaction (PCR). Each PCR reaction was performed in a $10 \mu \mathrm{L}$ volume, containing $1.5 \mathrm{mM} \mathrm{MgCl}, 0.6 \mu \mathrm{M}$ of each forward and reverse primer, $0.2 \mathrm{mM}$ dNTPs, $1 \mathrm{U}$ Taq DNA polymerase and PCR buffer $\left[16 \mathrm{mM}\left(\mathrm{NH}_{4}\right){ }_{2} \mathrm{SO}_{4}, 67 \mathrm{mM}\right.$ Tris- $\mathrm{HCl}(\mathrm{pH} 8.8$ ), and $0.01 \%$ of the nonionic detergent Tween-20] (Bioline Reagents Ltd., London, UK). Amplification was performed with an initial denaturation for $4 \mathrm{~min}$. at $94{ }^{\circ} \mathrm{C}$, followed by 35 cycles of denaturation at $94{ }^{\circ} \mathrm{C}$ for 35 seconds, annealing at $55{ }^{\circ} \mathrm{C}$ for 35 seconds, extension at $72{ }^{\circ} \mathrm{C}$ for 35 seconds, and a final extension at $72{ }^{\circ} \mathrm{C}$ for $7 \mathrm{~min}$. The PCR products were separated on $10.0 \%$ nondenaturing polyacrylamide gels (Protogel; National Diagnostics, Edinburgh, Scotland, UK). The gel was stained with ethidium bromide and photographed

Table 1. List of short tandem repeat markers used for genotyping in clinical anophthalmia.

\begin{tabular}{|c|c|c|c|c|}
\hline Chromosome & Gene & STR Markers & $\begin{array}{c}\text { Distance } \\
(\mathrm{cM})\end{array}$ & $\begin{array}{c}\text { Amplified } \\
\text { Length (bp) }\end{array}$ \\
\hline $14 q 32$ & - & $\begin{array}{l}\text { D14S617 } \\
\text { GATA168F06 } \\
\text { GATA136B01 }\end{array}$ & $\begin{array}{l}91.0 \\
92.6 \\
97.0\end{array}$ & $\begin{array}{l}141-173 \\
212-232 \\
133-157\end{array}$ \\
\hline $14 \mathrm{q} 24.3$ & CHX10 & $\begin{array}{l}\text { D14S588 } \\
\text { D14S53 } \\
\text { D14S606 }\end{array}$ & $\begin{array}{l}71.0 \\
82.7 \\
85.9 \\
\end{array}$ & $\begin{array}{l}117-141 \\
151-155 \\
254-286 \\
\end{array}$ \\
\hline $18 \mathrm{q} 21.3$ & $R A X$ & $\begin{array}{l}\text { D18S858 } \\
\text { ATA7D07 } \\
\text { D18S64 }\end{array}$ & $\begin{array}{l}54.9 \\
64.7 \\
60.1\end{array}$ & $\begin{array}{l}193-208 \\
126-147 \\
188-208\end{array}$ \\
\hline $14 q 21-22$ & OTX2 & $\begin{array}{l}\text { GATA168F06 } \\
\text { GATA136B01 }\end{array}$ & $\begin{array}{l}92.6 \\
97.0\end{array}$ & $\begin{array}{l}212-232 \\
133-157\end{array}$ \\
\hline $3 q 26.3-q 27$ & SOX2 & $\begin{array}{l}\text { D3S1565 } \\
\text { D3S2427 } \\
\text { D3S1262 } \\
\text { D3S2436 } \\
\text { D3S1580 } \\
\text { D3S1311 }\end{array}$ & $\begin{array}{l}190.3 \\
192.1 \\
205.2 \\
208.5 \\
208.7 \\
213.1\end{array}$ & $\begin{array}{l}239-245 \\
203-245 \\
100-132 \\
164-180 \\
139-155 \\
128-160\end{array}$ \\
\hline
\end{tabular}

cM: centimorgan; bp: base pair. 
under UV illumination. Alleles were assigned to individuals and genotypic data was used to find genotypes of all individuals of this family. The phenotype was analyzed as an autosomal recessive trait.

Mutation Screening. All individuals of this family were screened for mutations in the candidate gene. Polymerase chain reaction amplification of DNA of both normal and affected individuals was performed with forward and reverse primers sets, spanning the whole exonic region and promoter region of the candidate gene (Tables 2 and 3 ) that were designed using online available Primer 3 (http:// primer3plus.comweb_3.0.0/primer3web_input. htm) software. The PCR amplification was performed in a $50 \mu \mathrm{L}$ reaction volume containing $250 \mathrm{ng}$ of genomic DNA, amplification buffer containing $600 \mathrm{nM}$ of each primer, $1.5 \mathrm{mM} \mathrm{MgCl} 2,200 \mathrm{mM}$ of dNTPs and $2.5 \mathrm{U}$ of Taq DNA polymerase (Applied Biosystems
Ltd., Warrington, Cheshire, UK) in an PxE thermal cycler (Hybaid, Basingstoke, Hampshire, UK). The amplification conditions were $95^{\circ} \mathrm{C}$ for $5 \mathrm{~min}$., followed by 35 cycles of $95{ }^{\circ} \mathrm{C}$ for 45 seconds, primer specific annealing temperature $\left(55\right.$ to $\left.65^{\circ} \mathrm{C}\right)$ for 45 seconds, and $72{ }^{\circ} \mathrm{C}$ for 45 seconds. Aliquots $(5 \mu \mathrm{L})$ of the PCR products were analyzed by 2 to $2.5 \%$ agarose gel. The PCR products were then purified using QIAquick PCR Purification Kit (Qiagen Ltd., Crawley, West Sussex, UK) and sequenced directly using Big Dye ${ }^{\circledR}$ Terminator $v 3.1$ cycle sequencing kit in an ABI PRISM ${ }^{\circledR} 3130$ genetic analyzer (Applied Biosystems, Foster City, CA, USA).

\section{RESULTS}

In an ascertained consanguineous family with isolated clinical anophthalmia, the phenotypically

Table 2. Primer sets used for amplification of the single exon of the SOX2 gene.

\begin{tabular}{|l|l|c|}
\hline Primers & Sequences $\left(\mathbf{5}^{\prime}>\mathbf{3}{ }^{\prime}\right)$ & \multicolumn{1}{|c|}{$\begin{array}{c}\text { PCR Fragment } \\
\text { Size (bp) }\end{array}$} \\
\hline $\begin{array}{l}\text { Sox2_1aF } \\
\text { Sox2_1aR }\end{array}$ & $\begin{array}{l}\text { CCT CTC TCT TTT TTT CCC C } \\
\text { TCT CCG ACA AAA GTT TCC }\end{array}$ & 431 \\
\hline $\begin{array}{l}\text { Sox2_1bF } \\
\text { Sox2_1bR }\end{array}$ & $\begin{array}{l}\text { GCG GCA ACC AGA AAA ACA } \\
\text { GCA GCG TGT ACT TAT CCT T }\end{array}$ & 291 \\
\hline $\begin{array}{l}\text { Sox2_1cF } \\
\text { Sox2_1cR }\end{array}$ & $\begin{array}{l}\text { GCT CAT GAA GAA GGA TAA GT } \\
\text { GCT GGT CAT GGA GTT GTA }\end{array}$ & 283 \\
\hline $\begin{array}{l}\text { Sox2_1dF } \\
\text { Sox2_1dR }\end{array}$ & $\begin{array}{l}\text { CAT GAA CGG CTG GAG CAA } \\
\text { AGT GCT GGG ACA TGT GAA }\end{array}$ & 407 \\
\hline $\begin{array}{l}\text { Sox2_1eF } \\
\text { Sox2_1eR }\end{array}$ & $\begin{array}{l}\text { TTA CCT CTT CCT CCC ACT C } \\
\text { CTC CAT GCT GTT TCT TAC T }\end{array}$ & 286 \\
\hline
\end{tabular}

PCR: polymerase chain reaction; bp: base pair; F: forward; R: reverse.

Table 3. Primer sets used for amplification of the promoter sequence of the $S O X 2$ gene.

\begin{tabular}{|c|c|c|}
\hline Primers & Sequences $\left(5^{\prime}>3^{\prime}\right)$ & $\begin{array}{l}\text { PCR Fragment } \\
\text { Size (bp) }\end{array}$ \\
\hline $\begin{array}{l}5^{\prime} \mathrm{F} 2 \\
5^{\prime} \mathrm{R} 3\end{array}$ & $\begin{array}{l}\text { AGT CCC GGC CGG GCC GAG } \\
\text { GGT AGC CCA GCT GGT CCT G }\end{array}$ & 602 \\
\hline $\begin{array}{l}3^{\prime} \mathrm{F} \\
3^{\prime} \mathrm{R}\end{array}$ & $\begin{array}{l}\text { GGC GTG AAC CAG CGC ATG G } \\
\text { GGA GCG TAC CGG GTT TTC TC }\end{array}$ & 612 \\
\hline $\begin{array}{l}\text { 5'UTR F } \\
\text { 5'UTR R }\end{array}$ & $\begin{array}{l}\text { CGC TGA TTG GTC GCT AGA A } \\
\text { CTT CAG CTC CGT CTC CAT CAT }\end{array}$ & 518 \\
\hline $\begin{array}{l}\text { 3'UTR.1F } \\
\text { 3'UTR.1R }\end{array}$ & $\begin{array}{l}\text { GGG GTG CAA AAG AGG AGA GTA } \\
\text { GAA AAA TAT TGG CAA ATT CTC GC }\end{array}$ & 490 \\
\hline $\begin{array}{l}\text { 3'UTR.2F } \\
\text { 3'UTR.2R }\end{array}$ & $\begin{array}{l}\text { AAC ATG GCA ATC AAA ATG TCC } \\
\text { ATT CTC GGC AGA CTG ATT CAA }\end{array}$ & 514 \\
\hline $\begin{array}{l}\text { 3'UTR.3F } \\
\text { 3'UTR.3R }\end{array}$ & $\begin{array}{l}\text { CCC CCT TTA TTT TCC GTA GTT } \\
\text { ATC ATC CAG CCG TTT CTT TTT }\end{array}$ & 353 \\
\hline
\end{tabular}

PCR: polymerase chain reaction; bp: base pair; F: forward; R: reverse; 5'UTR: 5' untranslated region; 3'UTR: 3' untrans-lated region. 
normal parents with pedigree ID 2MOP001and 2MOP002, produced two affected daughters with pedigree ID 2MOP003 and 2MOP 006 (Figure 3). The proband, (2MOP003), was the first daughter identified with bilateral clinical anophthalmia, and she helped in tracing the disease in this family. Bilateral clinical anophthalmia was present at birth in both the affected daughters and the ages of these affected daughters were between 4-13 years.

In this study, no evidence of linkage was observed with any of the STR markers for the $14 \mathrm{q} 32$, $14 \mathrm{q} 24.3,18 \mathrm{q} 21.3$ and $14 \mathrm{q} 21-22$ loci and were therefore excluded. However, in view of the obtained results, this family with clinical anophthalmia was mapped to a locus on chromosome 3q26.3-q27, where the $S O X 2$ gene resides, as affected daughters showed homozygosity for this locus within a $3 \mathrm{cM}$ (centimorgan) in this region for STR markers D3S 2427, D3S1262, D1S2436 and D3S1580 (Figure 4).
In the pedigree under study, the parents of the affected daughters were first cousins, and both carried the same disease chromosome in a heterozygous state (Figure 3). However, the mutations were not identified in the single exonic sequence and regulatory element of the SOX2 gene by comprehensive mutational analysis of both normal and affected individuals. Only two individuals were found to be affected, thus, the Lod score genes could not be calculated to examine the combined effects of the genes.

\section{DISCUSSION}

The term clinical anophthalmia was first used by Duke-Elder [8], and is a rare disease. The reported average prevalence of congenital anophthalmia is three in 100,000 [14]. Clinical anophthalmia is the absence of the eye and diagnosed without histological examination [22]. The most common phenotype

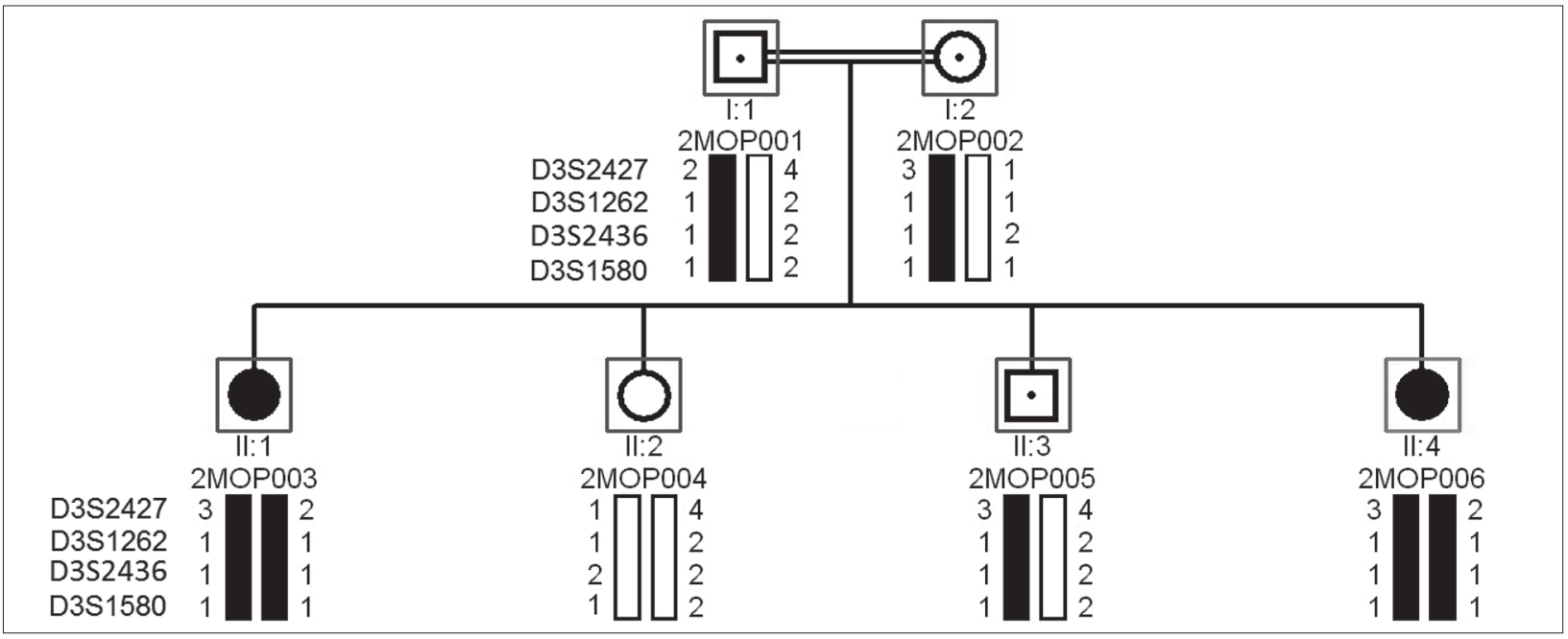

Figure 3. Pedigree of a consanguineous Pakistani family with STR genotyping data mapped to a locus on chromosome 3q26.3-q27. Both parents are carriers of the defective (boxed) chromosome. The affected individuals (filled square and circles) are homozygotes for the defective chromosome.

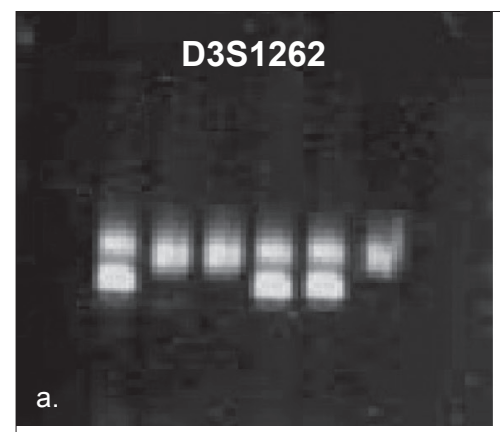

$1 / 21 / 11 / 11 / 21 / 21 / 1$

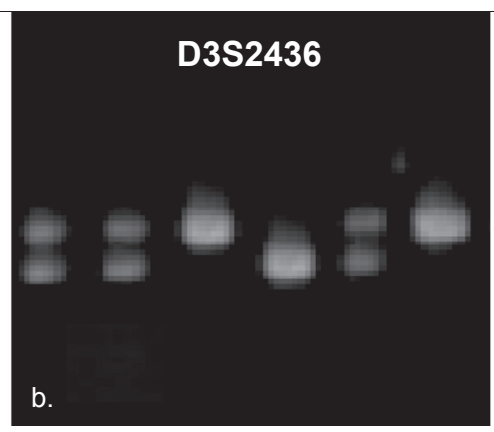

$\begin{array}{llllll}1 / 2 & 1 / 2 & 1 / 1 & 2 / 2 & 1 / 2 & 1 / 1\end{array}$

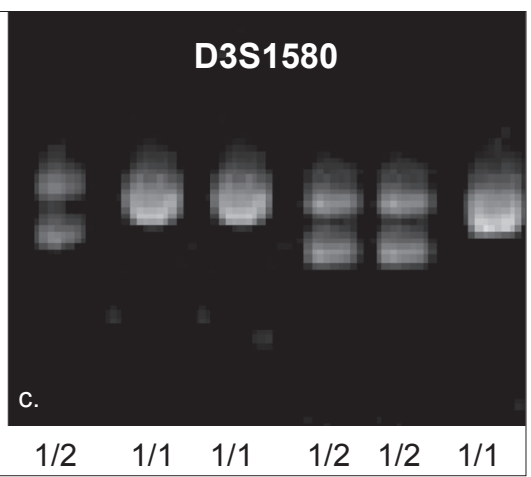

$\begin{array}{llllll}1 / 2 & 1 / 1 & 1 / 1 & 1 / 2 & 1 / 2 & 1 / 1\end{array}$

Figure 4. Gel electropherograms for STR markers D3S1262, D3S2436 and D3S1580, demonstrating homozygosity for the affected members (2MOP003 and 2MOP006) in the studied family. 
in affected individuals is bilateral anophthalmia [4], and unilateral anophthalmia may rarely be seen [5].

In the present study, we reported a consanguineous family with two affected daughters of isolated clinical anophthalmia from the Kohat region of Khyber Pakhtunkhwa, Pakistan. Affected daughters do not have any congenital malformations except for bilateral clinical anophthalmia. In addition, the family history showed that there was no other member with anophthalmia. In the pedigree under study, the affected daughters have unaffected parents, who are first cousins, thus inheritance is undoubtedly autosomal recessive. Moreover, members of this family practiced consanguineous marriages to follow the family tradition of marriages between cousins. Consanguinity in a family as a risk factor and consequently autosomal recessive mode of inheritance for clinical anophhalmia, has rarely been reported $[1,8,10,11]$. However, X-linked inher-itance has been described for clinical anophthalmia [4,23]. Epidemiological studies have also reported other risk factors including late maternal age, multiple births, low birth weight, premature birth complications, mechanical abortion and severe vitamin A deficiency $[4,15,16,18]$. These risk factors were not identified in this family as a cause of clinical anophthalmia.

In the present study, linkage analysis of family was performed with STR markers corresponding to the candidate genes involved in clinical anophthalmia phenotypes. This Pakistani family was linked to a locus at chromosome 3q26.3-q27, which carries the $S O X 2$ gene. The critical disease region was flanked by STR markers D3S1565 and D3S1311 in the affected daughters; therefore, it is probable that the disease gene lies between these two markers within a region of approximately $23 \mathrm{cM}$ on chromosome 3. However, the affected daughters showed homozygosity in the disease region of approximately $3 \mathrm{cM}$ for markers D3S 1262, D1S2436 and D3S1580. The linkage data presented in this study suggested that a gene for clinical anophthalmia was present within the region of homozygosity at chromosome 3 . However, mutation screening did not reveal any mutation in the exonic sequence and regulatory element of the $S O X 2$ gene in the parents and offspring of this family. This indicates that another gene might possibly be present in the mapped region for disease phenotype and needs to be identified and screened to identify the disease-associated mutation in this family. The Lod score calculation in linkage analysis is very successful in mapping Mendelian disease genes or to examine combined effects of genes. However, the Lod score could not be calculated, as there were only two affected daughters, and that is the limitation of our study.

The severity of clinical anophthalmia is variable due to mutations in various human genes that are associated with anophthalmia [4,5]. Among these, the $S O X 2$ has been reported as a major causative gene for clinical anophthalmia [4]. By genetic analysis, the single-exon $S O X 2$ gene was identified in an intron of a noncoding SOX2OT (SOX2 overlapping transcript) gene [24]. By using the fluorescent in situ hybridization (FISH) approach, the $\mathrm{SOX} 2$ gene was mapped to chromosome 3q26.3-q27 [25]. The SOX2 gene is universally expressed in neural stem and neural precursor cells throughout the central nervous system including the neural retina [26-28], and mutations in this gene are common causes of retinal and ocular malformations in humans.

By sequence analysis of the coding region of the SOX2 gene, a heterozygous loss-of-function mutation was identified in individuals with unilateral and bilateral anophthalmia in various research studies. By SOX2 mutation analysis in four unrelated individuals with unilateral or bilateral clinical anophthalmia, Fantes et al. [24] identified heterozygous de novo truncating mutations in the SOX2 gene. Similarly, in an 11-month-old Mexican female infant with bilateral clinical anophthalmia and brain malformations, Zenteno et al. [29] identified heterozygosity for a $20 \mathrm{bp}$ deletion in the SOX2 gene. De novo missense mutations and frameshift mutations in the heterozygous state in the coding region of the SOX2 gene in patients with bilateral anophthalmia/ microphthalmia were also reported [30].

In a 12-year-old girl with congenital bilateral clinical anophthalmia, a heterozygous nonsense mutation in the SOX2 gene was found [31]. Similarly, a heterozygous missense mutation was found in the SOX2 gene in a girl with bilateral clinical anophthalmia. However, the clinically normal mother was found to be heterozygous for this mutation [32]. The SOX2 gene was analyzed in two female siblings with clinical bilateral anophthalmia and found heterozygosity for a $17 \mathrm{bp}$ deletion on this gene $[6,33]$. Similarly, in an Italian male with clinical bilateral anophthalmia and micropenis, a heterozygous insertion mutation was reported in the $S O X 2$ gene responsible for such phenotypes [34]. 


\section{CONCLUSIONS}

In conclusion, the phenotypically normal parents of the affected daughters were first cousins, and both carried disease chromosome in the heterozygous state, and their affected daughters were homozygotes. Therefore, the present study strongly supports the fact on the basis of pedigree and linkage analysis that the consanguineous marriage contributed to the congenital isolated clinical anophthalmia that is inherited in an autosomal recessive manner. Moreover, this study could not reveal a molecular basis for congenital clinical anophthalmia in this family, as a consequence of mutations in the $S O X 2$ gene. If more samples of congenital clinical anophthalmia subjects would be investigated in families of the same ethnic group, a better estimation of disease-related genes other than $S O X 2$, but not yet identified in congenital isolated clinical anophthalmia, could be made in future.

\section{ACKNOWLEDGMENTS}

We acknowledge the contribution of Dr. Muhammad Arif, Department of Ophthalmology, Khyber Medical University (KMU) Institute of Medical Sciences, Kohat, Khyber Pakhtunkhwa, Pakistan, in the clinical assessment of patients with anophthalmia. The authors would also like to thank the patients and their family members for their participation in this study.

Declaration of Interest. The authors report no conflicts of interest. The authors alone are responsible for the content and writing of this article.

\section{REFERENCES}

1. Pearce WG, Nigam S, Rootman J. Primary anophthalmos. Histological and genetic features. Can J Ophthalmol. 1974; 9(1): 141-145.

2. McLean CJ, Ragge NK, Jones RB, Collin JRO. The management of orbital cysts associated with congenital microphthalmos and anophthalmos. Br J Ophthalmol. 2003; 87(7): 860-863.

3. Bernardino CR. Congenital anophthalmia: A review of dealing with volume. Middle East Afr J Ophthalmol. 2010; 17(2): 156-160.
4. Verma AS, FitzPatrick DR. Anophthalmia and microphthalmia. Orphanet J Rare Dis. 2007; 2(11): 47-54.

5. Reis LM, Tyler RC, Schneider A, Bardakjian T, Semina EV. Examination of SOX2 in variable ocular conditions identifies a recurrent deletion in microphthalmia and lack of mutations in other phenotypes. Mol Vis. 2010; 16(4): 768-773.

6. Schneider A, Bardakjian TM, Zhou J, Hughes $\mathrm{N}$, Keep R, Dorsainville D, et al. Familial recurrence of SOX2 anophthalmia syndrome: Phenotypically normal mother with two affected daughters. Am J Med Genet A. 2008; 146(21): 2794-2798. doi: 1002/ajmg.a.32384.

7. Shah SP, Taylor A, Sowden JC, Ragge NK, Russell-Eggitt I, Rahi JS, et al. Anophthalmos, microphthalmos and typical coloboma in the UK: A prospective study of incidence and risk. Invest Ophthalmol Vis Sci. 2011; 52(1): 558-564.

8. Duke-Elder S. Anophthalmos and extreme microphthalmos: System of Ophthalmology. St Louis, MO, USA: Mosby Year Book, Inc. 1964: 416-423.

9. Zhou J, Kherani F, Bardakjian TM, Katowitz J, Hughes N, Schimmenti LA, et al. Identification of novel mutations and sequence variants in the SOX2 and CHX10 genes in patients with anophthalmia/microphthalmia. Mol Vis. 2008; 14(3): 583-592.

10. Joseph RA. Pedigree of anophthalmos. Br J Ophthalmol. 1957; 41(9): 541-543.

11. Oliveira da Silva E, Santana de Sousa S. Clinical anophthalmia. Hum Genet. 1981; 57(1):115-116.

12. Gonzalez-Rodriguez J, Pelcastre EL, TovillaCanales JL, Garcia-Ortiz JE, Amato-Almanza $\mathrm{M}$, Villaneuva-Mendoza $\mathrm{C}$, et al. Mutational screening of CHX10, GDF6, OTX2, RAX and SOX2 genes in 50 unrelated microphthalmiaanophthalmia-coloboma (MAC) spectrum cases. Br J Ophthalmol. 2010; 94(8): 1100-1104.

13. Morrison D, FitzPatrick D, Hanson I, Williamson $\mathrm{K}$, van Heyningen V, Fleck B, et al. National study of microphthalmia, anophthalmia, and coloboma (MAC) in Scotland: Investigation of genetic aetiology. J Med Genet. 2002; 39(1): 16-22.

14. Campbell H, Holmes E, MacDonald S, Morrison D, Jones I. A capture-recapture model to 
estimate prevalence of children born in Scotland with developmental eye defects. J Cancer Epidemiol Prev. 2002; 7(1): 21-28.

15. Shaw GM, Carmichael SL, Yang W, Harris JA, Finnell RH, Lammer EJ. Epidemiologic characteristics of anophthalmia and bilateral microphthalmia among 2.5 million births in California, 1989-1997. Am J Med Genet A. 2005; 137(1): 36-40.

16. Kallen B, Tornqvist K. The epidemiology of anophthalmia and microphthalmia in Sweden. Eur J Epidemiol. 2005; 20(4): 345-50.

17. Lowry RB, Kohut R, Sibbald B, Rouleau J. Anophthalmia and microphthalmia in the Alberta congenital anomalies surveillance system. Can J Ophthalmol. 2005;40(1): 38-44.

18. Forrester MB, Merz RD. Descriptive epidemiology of anophthalmia and microphthalmia in Hawaii, 1986-2001. Birth Defects. Res A Clin Mol Teratol. 2006; 76(3): 187-192.

19. Hussain R, Bittles AH. The prevalence and demographic characteristics of consanguineous marriages in Pakistan. J Biosoc Sci. 1998; 30(2): 261-275.

20. Bittles AH. Consanguinity and its relevance to clinical genetics. Clin Genet. 2001; 60(2): 89-98.

21. Maniatis T, Fritsch EF, Sambrook J. Molecular Cloning: A Laboratory Manual, 2nd ed. Cold Spring Harbor, NY, USA: Cold Spring Harbor Laboratory Press, 1982.

22. O'Keefe M, Webb M, Pashby RC, Wagman RD. Clinical anophthalmos. Br J Ophthalmol. 1987; 71(8): 635-638.

23. Brunquell PJ, Papale, JH, Horton JC, Williams RS, Zgrabik MJ, Albert DM, et al. Sex-linked hereditary bilateral anophthalmos. Arch Ophthalmol. 1984; 102(1): 108-113.

24. Fantes JA, Ragge NK, Lynch SA, McGill NI, Collin JR, Howard-Peebles PN, et al. Mutations in SOX2 cause anophthalmia. Nat Genet. 2003; 33(4): 461-463.

25. Stevanovic M, Zuffardi O, Collignon J, LovellBadge R, Goodfellow P. The cDNA sequence and chromosomal location of the human SOX2 gene. Mamm Genome. 1994; 5(10): 640-642.
26. D'Amour KA, Gage FH. Genetic and functional differences between multipotent neural and pluripotent embryonic stem cells. Proc Natl Acad Sci USA. 2003; 100(Suppl 1): 11866-11872.

27. Ellis $P$, Fagan BM, Magness S, Hutton S, Taranova O, Hayashi S, et al. SOX2, a persistent marker for multi-potential neural stem cells derived from embryonic stem cells, the embryo or the adult. Dev Neurosci. 2004; 26(2): 148-165.

28. Ferri ALM, Cavallaro M, Braida D, Di Cristofano A, Canta A, Vezzani A, et al. SOX2 deficiency causes neurodegeneration and impaired neurogenesis in the adult mouse brain. Development. 2004; 131(15): 3805-3819.

29. Zenteno JC, Gascon-Guzman G, Tovilla-Canales JL. Bilateral anophthalmia and brain malformations caused by a 20-bp deletion in the SOX2 gene. (Letter) Clin Genet. 2005; 68(6): 564-566.

30. Ragge, NK, Lorenz B, Schneider A, Bushby K, de Sanctis L, de Sanctis U, et al. SOX2 anophthalmia syndrome. Am J Med Genet A. 2005; 135(1): 1-7.

31. Hagstrom SA, Pauer GJT, Reid J, Simpson E, Crowe $\mathrm{S}$, Maumenee $\mathrm{IH}$, et al. SOX2 mutation causes anophthalmia, hearing loss, and brain anomalies. Am J Med Genet A. 2005; 138(2): 95-98.

32. Faivre L, Williamson KA, Faber V, Laurent N, Grimaldi M, Thauvin-Robinet C, et al. Recurrence of SOX2 anophthalmia syndrome with gonosomal mosaicism in a phenotypically normal mother. Am J Med Genet A. 2006; 140(6): 636-639.

33. Chassaing N, Gilbert-Dussardier B, Nicot F, Fermeaux V, Encha-Razavi F, Fiorenza M, et al. Germinal mosaicism and familial recurrence of a SOX2 mutation with highly variable phenotypic expression extending from AEG syndrome to absence of ocular involvement. Am J Med Genet A. 2007; 143(3): 289-291.

34. Pedace L, Castori M, Binni F, Pingi A, Grammatico B, Scommegna S, et al. A novel heterozygous SOX2 mutation causing anophthalmia/ microphthalmia with genital anomalies. Eur J Med Genet. 2009; 52(4): 273-276. 